\title{
Game Edukasi Museum Adityawarman Berbasis Android
}

\author{
Robby Usman \\ Universitas Putra Indonesia YPTK Padang \\ E-mail: robbyusman1@gmail.com
}

\begin{abstract}
Abstrak
Museum is a vehicle that has a strategic role in strengthening people's identity. One of the museums that exhibits historical relics is the State Museum of West Sumatra Province, known as the Adityarwan Museum. The Adityawarman Museum is the most important cultural museum in West Sumatra. The museum functions as a place to store and preserve historical objects, such as: Minangkabau cultural heritage, Mentawai cultural heritage and other archipelago cultural heritage. The use of smartphones, iPads, playbooks, tablet PCs and the like is more widely used today for various reasons and choices than PCs (Personal Computers) at home. In addition, there are many game features that are not only for entertainment, but there are already many games to hone thinking and logic that can educate children. Android is an operating system for Linux-based mobile devices which includes an operating system, middleware, and applications. Android provides an open platform for developers to create their applications. Android is the operating system that powers more than a billion smartphones and tablets
\end{abstract}

Keywords: Adityawarman Museum, Educational Game, Android

\begin{abstract}
Abstrak
Museum merupakan wahana yangmemiliki peranan strategis terhadap penguatan identitas masyarakat. Salah satu museum yang memamerkan peninggalan bersejarah adalah Museum Negeri Provinsi Sumatera Barat yang dikenal dengan Museum Adityarwan. Museum Adityawarman merupakan museum budaya terpenting di Sumatera Barat. Museum tersebut berfungsi sebagai tempat menyimpan dan melestarikan benda-benda sejarah, seperti:cagar budaya Minangkabau, cagar budaya Mentawai dan cagar budaya Nusantara lainnya. Penggunaan smartphone, ipad, playbook, tablet pc dan sejenisnya lebih banyak digunakan saat ini karena berbagai alasan dan pilihan daripada PC (Personal Computer) yang ada dirumah. Selain itu, terdapat banyak fitur game yang tidak hanya sebagai hiburan bermain, namun sudah banyak game untuk mengasah daya pikir dan logika yang dapat mengedukasi anak-anak. Android adalah sebuah sistem operasi untuk perangkat mobile berbasis linux yang mencakup sistem operasi, middleware, dan aplikasi. Android menyediakan platform terbuka bagi para pengembang untuk menciptakan aplikasi mereka. Android adalah sistem operasi yang menghidupkan lebih dari satu miliar smartphone dan tablet.
\end{abstract}

Kata kunci: Museum Adityawarman, Game Edukasi, Android

\section{Pendahuluan}

Museum merupakan wahana yangmemiliki peranan strategis terhadap penguatan identitas masyarakat. Para ahli kebudayaan meletakkan museum sebagai bagian dari pranata sosial dan sebagai wahana untuk memberikan gambaran dan mendidik perkembangan alam dan budaya manusia kepada komunitas dan publik. Melalui pandangan museum sebagai objek wisata yang menarik dan menyenangkan, akan meningkatkan apresiasi dan rasa ingin berwisata ke museum di kalangan pemuda yang datang untuk menyaksikan benda-benda koleksi museum. Selain sifatnya yang dirasa langsung ketika berkunjung ke museum, manfaat lainnya yakni berupa kesadaran akan pentingnya sejarah dan peradaban suatu bangsa sebagai media representasi bagi generasi di masa yang akan datang. Salah satu museum yang memamerkan peninggalan bersejarah adalah Museum Negeri Provinsi Sumatera Barat. Museum tersebut dibangun pada tahun 1974 dan diresmikan pada tanggal 16 Maret 1977. Pada tanggal 28 Mei 1979, museum tersebut diberi nama "Adityawarman" dan berlokasi di jalan Diponegoro Nomor 10, Kota Padang-Sumatera Barat. Nama Adityawarman diambil dari nama seorang Raja besar yang pernah berkuasa di Minangkabau, sezaman dengan Kerajaan Majapahit pada masa Patih Gajah Mada(Kepala Dinas Kebudayaan dan Pariwisata (Kadisbudpar) Sumatera Barat: Padang, 20/2/2016). Museum Adityawarman merupakan museum budaya terpenting di Sumatera Barat. Museum tersebut berfungsi sebagai tempat menyimpan dan melestarikan benda-benda sejarah, seperti:cagar budaya Minangkabau, cagar budaya Mentawai dan 
cagar budaya Nusantara lainnya. Untuk menjaga kelestarian koleksi benda-benda bersejarah tersebut,pemerintah setempat membentuk tim kecil yang bertugas sebagai tenaga educator, konservator, preparator dan Pustakawan. Untuk meningkatkan minat masyarakat terhadap museum, museum Adityawarman dalam pelayanannya kepada masyarakat telah melakukan kegiatan pameran hampir setiap tahun sebanyak 5 (lima) atau 6 (enam) kali.Pengunjung museum kebanyakan hanya tertarik berekreasi ditamannya saja, hanya sebagian kecil yang ingin masuk dan melihat isi dari Museum Adityawarman. Fenomena ini terjadi hampir setiap hari dan pada hari libur pengunjung semakin banyak, akan tetapi hanya sebatas ingin berekreasi ditaman saja, bukan masuk ke dalam museum. Sungguh disayangkan jika museum hanya dianggap sebagai rekreasi taman saja tanpa menambah nilai positif bahwa museum dapat menjadi pusat pengembangan ilmu pengetahuan dan pusat pendidikan bagi masyarakat. Dari data yang diperoleh dapat ditarik kesimpulan bahwa kurangnya atau belum ada media promosi yang berimbang atau mutakhir yang dilakukan oleh pihak pemerintah (Museum). Maka dari itu diperlukan sebuah media promosi yang sangat efektif dan modern yang dapat diterima oleh masyarkat, yaitu Game Edukasi berbasis Android. Penggunaan smartphone, ipad, playbook, tablet pc dan sejenisnya lebih banyak digunakan saat ini karena berbagai alasan dan pilihan daripada PC (Personal Computer) yang ada dirumah. Selain itu, terdapat banyak fitur game yang tidak hanya sebagai hiburan bermain, namun sudah banyak game untuk mengasah daya pikir dan logika yang dapat mengedukasi anak-anak. Android adalah sebuah sistem operasi untuk perangkat mobile berbasis linux yang mencakup sistem operasi, middleware, dan aplikasi. Android menyediakan platform terbuka bagi para pengembang untuk menciptakan aplikasi mereka. Android adalah system operasi yang menghidupkan lebih dari satu miliar smartphone dan tablet. Melalui penelitian ini penulis akan membuat game edukasi yang bermanfaat positif bagi anak di antaranya, mengenal koleksi museum Adityawarman, mengenal teknologi informasi, dan tentunya mempromosikan museum Adityawarman sebagai wisata edukasi yang harus dikunjungi.

\section{Metode Penelitian}

Metode Analisis Data

Ada beberapa faktor yang mempengaruhi dan menjadi penghambat bertambahnya jumlah pengunjung, maka penelitian yang digunakan adalah metode SWOT (Strenght, Weakness, Opportunity dan Threatment).

\begin{tabular}{|c|c|c|}
\hline Faktor Internal & $\begin{array}{l}\text { Kekuatan (Strenght) } \\
-\quad \text { Keaslian benda-benda } \\
\text { koleksi. } \\
-\quad \text { Sarana dan prasarana } \\
\text { yang bagus. } \\
\text { - } \\
\text { Koleksi yang lengkap. } \\
\begin{array}{l}\text { Display pameran yang } \\
\text { menarik. }\end{array}\end{array}$ & \begin{tabular}{ll}
\multicolumn{2}{l}{ Kelemahan (Weakness) } \\
$-\quad$ & Media Promosi yang \\
& sedikit. \\
$-\quad$ & Kurangnya kegiatan \\
& promosi.
\end{tabular} \\
\hline $\begin{array}{cl}\text { Peluang (Opportunity) } \\
-\quad \text { Pengunjung. } \\
-\quad \text { Banyaknya } \\
\text { pelajar di } \\
\text { Sumatera Barat. } \\
\text { - } & \text { Meningkatnya } \\
& \text { wisatawan lokal } \\
\text { dan nasional yang } & \text { berkunjung ke } \\
\text { Sumatera Barat. } \\
\text { - Trend Booth } \\
\text { Stand }\end{array}$ & $\begin{array}{l}\text { Strenght } \rightarrow \text { Opportunity } \\
-\quad \text { Mempelihatkan } \\
\text { sebagian koleksi } \\
\text { museum ke sekolah. }\end{array}$ & $\begin{array}{l}\text { Weakness } \rightarrow \text { Opportunity } \\
-\quad \text { Membuatkan media } \\
\text { promosi untuk Museum } \\
\text { Adityawarman. }\end{array}$ \\
\hline
\end{tabular}




\begin{tabular}{|c|c|c|}
\hline $\begin{array}{c}\text { Ancaman(Threatment) } \\
-\quad \begin{array}{l}\text { Akses internet, } \\
\text { teknologi } \\
\text { informasi dan } \\
\text { multimedia } \\
\text { memudahkan } \\
\text { pelajar untuk } \\
\text { mencari tau } \\
\text { informasi tanpa } \\
\text { harus berkunjung } \\
\text { terlebih dahulu. } \\
\text { Malasnya pelajar } \\
\text { untuk datang dan } \\
\text { berkunjung. }\end{array} \\
\begin{array}{l}\text { langsung dengan } \\
\text { media promosi. }\end{array}\end{array}$ & $\begin{array}{l}\text { Weakness } \rightarrow \text { Threatment } \\
\text { Promosi yang lebih } \\
\text { inovatif dan lebih } \\
\text { bervariasi. } \\
\text { Jemput bola (mendatangi } \\
\text { sekolah-sekolah). }\end{array}$ \\
& & \\
\hline
\end{tabular}

\section{Metode Analisa Data}

a. Media Utama

Media utama adalah media yang paling efektif dan efisien yang dapat mendukung keberhasilan dalam "Game Edukasi Museum Adityawarman Berbasis Android". Media utama yang dipilih adalah media digital yang berbasiskan android.

b. Media Pendukung

Selain dari media utama juga dibuat media pendukung yang bertujuan mendukung media utama. Media pendukung yang dipilih antara lain : : poster, x-banner, sticker, gantungan kunci, mouse pad, topi, baju kaos, payung, billboard, pin, mook, dan note book.

c. Capaian Target Audience

Secara geografis target audience adalah Pelajar yang berada di kawasan Sumatera Barat serta masyarakat umum.

Dari segi aspek demografis adalah: semua pelajar dan masyarakat umum baik itu pria ataupun wanita.

Pada aspek psikografis, target audience yang di capai adalah yang memiliki rasa ingin tahu yang tinggi mengenai sejarah Minangkabau dan peninggalan sejarah yang ada di Museum Adityawarman. Sehingga bisa menambah wawasan pelajar mengenai Museum Adityawarman.

d. Studi Icon

Perancangan icon akan berangkat dari ornamen-ornamen yang ada di Museum Adityawarman seperti : Rumah Gadang, Rangkiang, ukiran dan bangunan Museum.

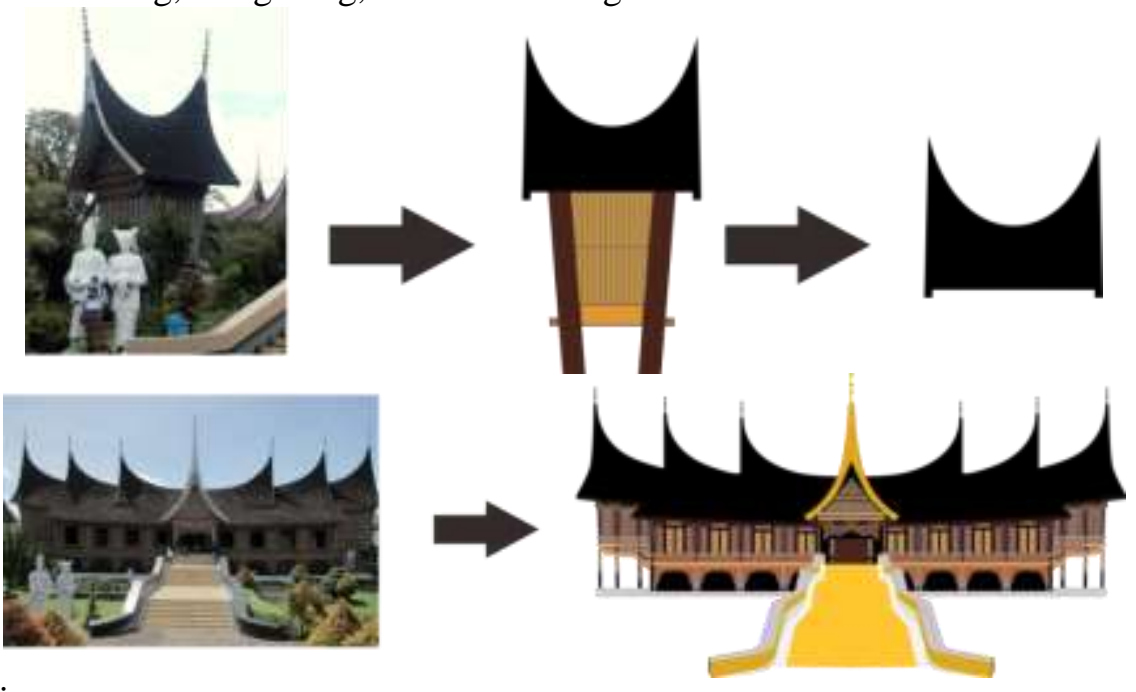

e. Studi Tagline

Tagline yang digunakan pada Multimedia Interaktif Museum Adityawarman berangkat dari tagline yang sudah ada "Ayooo kunjungi Museum Nagari” menjadi “ayo...jelajahi Museum Nagari” 
pengubahan tagline ini dimaksudkan agar bahasa yang digunakan lebih komunikatif tanpa merubah arti ataupun maksud dan tujuan dari tagline yang sudah ada.

f. Studi Warna

Warna yang dipakai adalah warna cerah guna untuk menambah nilai estetika dari flat design. Tetapi juga ada warna dominan yang akan di pakai pada icon dan media pendukung yaitu, warna Biru Muda dan Putih. Warna Biru Muda memiliki pengaruh yang tenang dan mendalam, Biru Muda juga memberikan kesan komunikasi.

\title{
Hasil Perancangan
}

\author{
a. Media Utama
}

adapun konsep visual dalam game edukasi ini adalah dengan menginterpretasikan kondisi Museum Adityawarman dalam bentuk flat design. Flat design adalah desain dengan pendekatan minimalis yang menekankan kegunaan, dengan desain yang bersih tanpa ada bevel, bayangan, tekstur, berfokus pada tipografi, warna-warna cerah dan ilustrasi dua dimensi. Ornamen-ornamen yang dipakai dalam media interaktif Museum Aditywarman adalah ornamen-ornamen yang dapat menggambarkan Museum Adityawarman itu sendiri seperti : Rumah Gadang, Rankiang, pohon kelapa dan sebagainya.

Sementara konsep game yang akan di suguhkan pada aplikasi ini adalah game tebak gambar. Pemain akan diberikan waktu untuk menebak gambar apa yang divisualkan sehingga, pemain akan menebak sebanyak-banyaknya dengan batas waktu yang diberikan. Apabila waktunya telah habis pemain juga dapat mengetahui berapa nilai yang di dapatkan setelah menebak gambar tersebut.
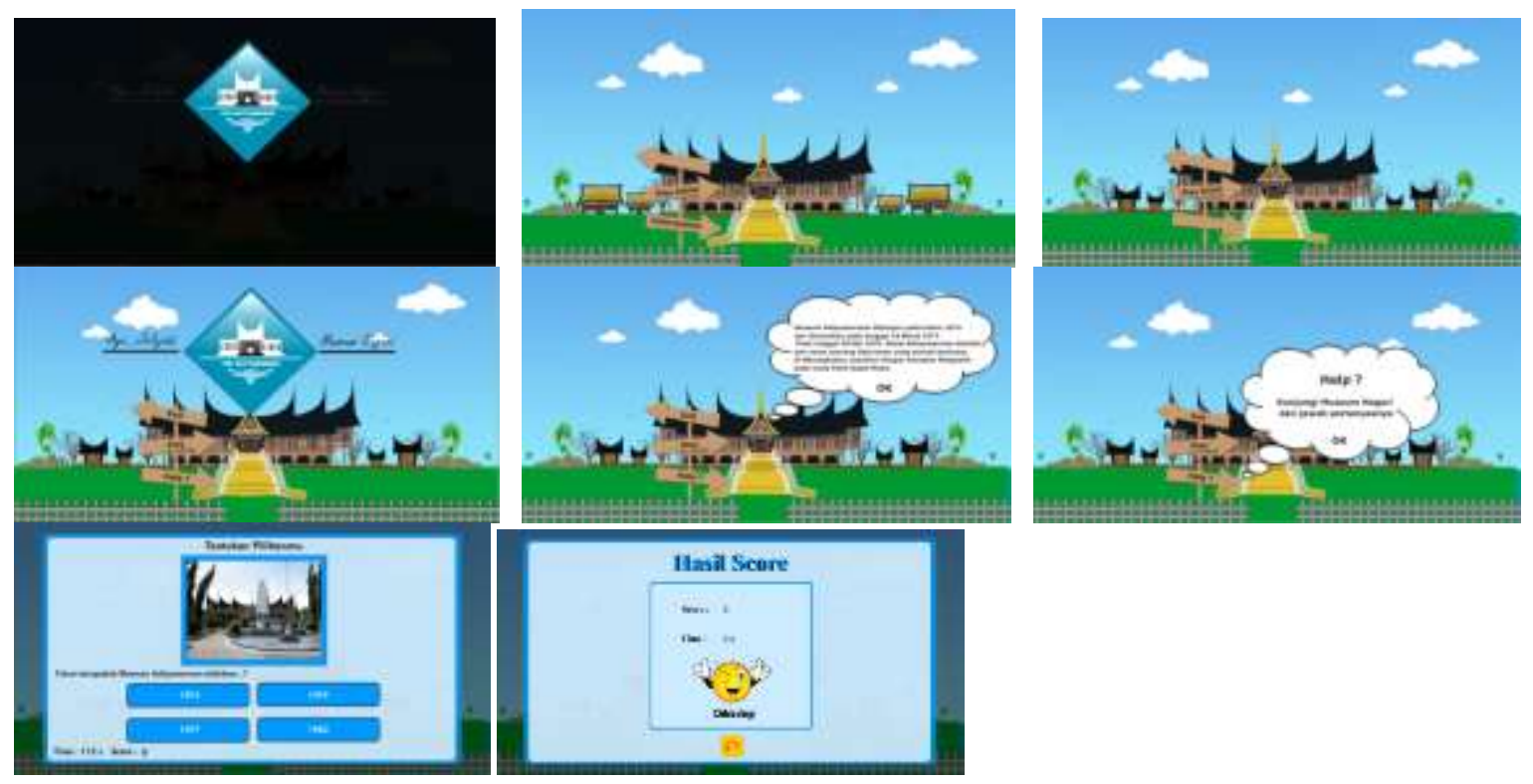

\section{b. Media Pendukung}

Selain dari media utama juga dibuat media pendukung yang bertujuan mendukung media utama. Penulis telah memilih media pendukung yang dapat menguatkan Game Edukasi Museum Adityawarman berbasis Android, seperti : poster, x-banner, sticker, gantungan kunci, mouse pad, topi, baju kaos, payung, billboard, pin, mook, dan note book. Kebanyakan dari media pendukung adalah merchandise karena media pendukung nantinya juga akan berfungsi sebagai reward dari game ini. 

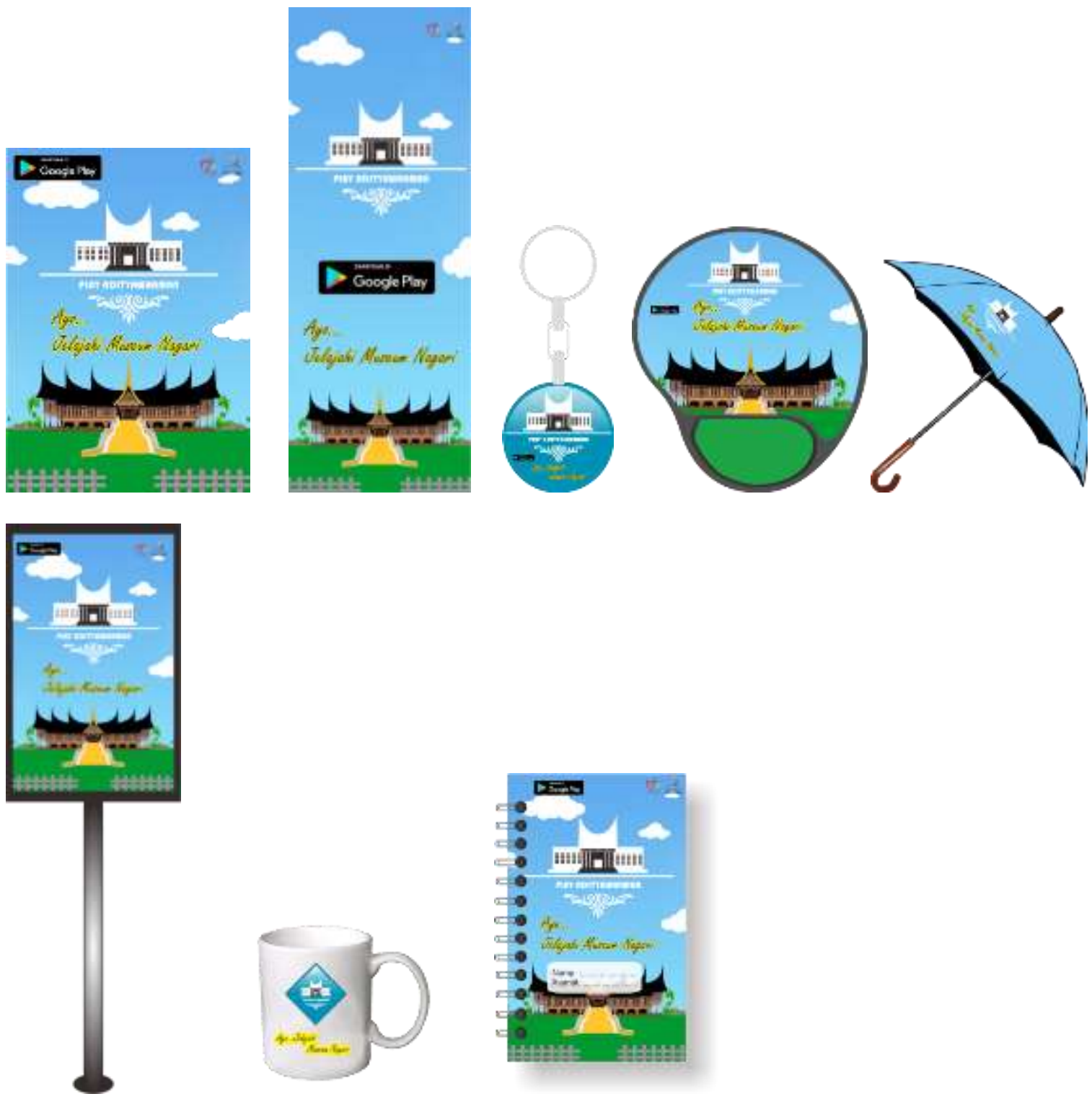

\section{Kesimpulan dan Saran}

Rancangan Game Edukasi Museum Adityawarman Berbasis Android diwujudkan dalam sebuah aplikasi android, dimana aplikasi dapat di akses di play store. Selain itu juga di rancang media pendukung yang akan mendukung keberhasilan dari media utama seperti, : poster, x-banner, sticker, gantungan kunci, mouse pad, topi, baju kaos, payung, billboard, pin, mook, dan note book. Kebanyakan dari media pendukung adalah merchandise karena media pendukung nantinya juga akan berfungsi sebagai reward dari game tebak gambar yang disajikan. Rancangan kreatif menjadi kunci dalam suksesnya Game Edukasi Museum Adityawarman Berbasis Android. Sesuai dengan tujuan dari penelitian ini adalah merancang game edukasi yang mampu memberikan efek positif dalam bermain dan menarik minat masyarakat khususnya pelajar untuk mengunjungi Museum Adityawarman.

Kepada rekan-rekan akademis, supaya tak henti-hentinya berkarya serta mulai mengembangkan pikiran untuk kemajuan Museum Nagari. Siapapun kita, selagi masih berada di kota Padang berarti kita bertanggung jawab terhadap perkenbangan kota. 


\section{Referensi}

[1] Cenadi, Christine S. Elemen-elemen dalam Desain Komunikasi Visual. Jurnal Nirmana volume 1 nomor 1, Universitas Kristen Petra, Surabaya, 1999

[2] Sarwono, Jonathan, dan Lubis, Hary. 2007 Metode Riset untuk Desain Komunikasi Visual. Yogyakarta. Penerbit Andi.

[3] Kusrianto, Adi. 2006. Pengantar Desain Komunikasi Visual. Yogyakarta: Andi

[4] Suyadi. Permainan Edukatif yang Mencerdaskan. Power Books Publishing, Yogyakarta, 2004. 